\title{
Analisis Implementasi Undang-Undang Nomor 41 Tahun 2004 Terhadap Legalitas Tanah Wakaf (Studi Di Kantor Kementerian Agama Kota Salatiga)
}

\author{
Sumarlan*
}

\begin{abstract}
Mahasiswa Program Magister (S2) IImu Hukum Fakultas Hukum UNISSULA Semarang, email: sumarlanjody5758@gmail.com
\end{abstract}

\section{ABSTRAK}

Islam memberikan pedoman, acuan terhadap keyakinan terhadap ummatnya dalam membrikan solusi dalam perjalananan hidup agar manusia mampu mengatasi persoalan persoalan hidup di dunia serta mencapai kebahagiaan yang kekal kelak di akhirat. Wakaf merupakan salah satu ajaran sangat penting dalam menjadi instrument berkait dengan pemberdayaan ummat serta solusi terhadap persoalan ekonomi ummat. Kelahiran UU Nomor 41 Tahun 2004 tentang Wakaf menandai era baru serta keseriusan pemerintah didalam melindungi serta mendukung pengelolaan harta benda wakaf. Dimana Badan Wakaf Indonesia (BWI) berperan sebagai regulator pengelolaan harta benda wakaf secara nasional, diharapkan mampu melaksanakan tugas dan fungsinya secara akuntabel dan profesional. Sangat menarik untuk dikupas tentang bagaimana pelaksanaan Undang-undang Nomor 41 tahun 2004 tentang Wakaf, hambatan-hambatan apa saja yang timbul dalam mengimplementasikan UndangUndang tersebut, serta bagaimana solusi atas hambatan-hambatan tersebut di lingkungan Kantor Kementerian Agama Kota Salatiga.

Pelaksanaan Undang-Undang Nomor 41 tahun 2004 tentang Wakaf ini membutuhkan integrasi serta integritas dari berbagai sektor terkait, ulama, Badan Wakaf Indonesia (BWI), serta Forum Nazhir, wakif, serta dukungan dari seluruh masyarakat. Badan Wakaf Indonesia diharapkan dapat lebih optimal dalam menjalankan tugas dan fungsinya serta meningkatkan akuntabilitas serta profesionalismenya demi pengelolaan harta benda wakaf yang lebih profesional

Kata Kunci : Wakaf, BWI, Undang-UndangNomo 41Tahun 2004

\section{ABSTRACT}

Islam provides guidance, reference to the belief in his ummah in membrikan solution in the course of life so that human beings able to overcome the problems of life in the world and achieve eternal happiness in the afterlife. Wakaf is one of the most important teachings in becoming an instrument related to the empowerment of the ummah as well as solutions to the economic problems of the ummah. The birth of Law No. 41 of 2004 on Wakaf marks a new era and the government's seriousness in protecting and supporting the management of wakaf property. Where Wakaf Board of Indonesia (BWI) acts as a regulator of wakaf property management nationally, is expected to perform its duties and functions in an accountable and professional manner.

It is interesting to discuss how the implementation of Law No. 41 of 2004 on Waqf, what constraints arise in implementing the Act, and how the solution to these barriers within the Ministry of Religious Affairs Office of Salatiga City.

The implementation of Law No. 41 of 2004 on Wakaf requires the integration and integrity of various related sectors, scholars, Wakaf Board of Indonesia (BWI), and Nazhir Forum, wakif, and support from all communities. Indonesian Waqf Board is expected to be more optimal in carrying out its duties and functions as well as increasing its accountability and professionalism for the management of wakaf property more professional.

Keywords: Endowments, BWI, Law No. 42 of 2004 


\section{PENDAHULUAN}

Wakaf secara epistemologis berasal dari kata kerja bahasa arab waqofa yang berarti berhenti, berdiam ditempat, atau menahan. Menurut Kamus Besar Bahasa Indonesia wakaf ialah memperuntukkan sesuatu bagi kepentingan umum, sebagai derma atau kepentingan yang berhubungan dengan agama. ${ }^{1}$

Sedangkan menurut Undang-UndangNomor 41 Tahun 2004 Tentang Wakaf, bahwa pengertian wakaf disebutkan dalam pasal 1 (satu) ayat 1 (satu) yaitu wakaf adalah perbuatan hukum wakif untuk memisahkan dan/atau menyerahkan sebagian harta benda miliknya untuk dimanfaatkan selamanya atau untuk jangka waktu tertentu sesuai dengan kepentingannya guna keperluan ibadah dan/atau kesejahteraan umum menurut syariah. Kemudian dalam ayat 2 (dua) disebutkan bahwa wakif adalah pihak yang mewakafkan harta benda miliknya. ${ }^{2}$

Dalam sejarah Islam wakaf dikenal sejak masa Rasulullah SAW berhijrah keMadinah pada tahun kedua hijriyah. Ada dua pendapat yang berkembang dikalangan ahli yurisprudensi (fuqaha) tentang siapa yang pertama kali melakukan syariatwakaf :

Pertama, pendapat ini mengatakan bahwa yang pertama kali melaksanakan wakaf adalah Rasulullah SAW, beliau mewakafkant anah untuk dibangun sebuah masjid.

Kedua, pendapat yang mengatakan bahwa yang pertama kali melaksanakan syariat wakaf adalah Ummar Bin Khattab. ${ }^{3}$

Bagi masyarakat muslim, wakaf memiliki nilai ajaran yang sangat tinggi dan mulia. Setidaknya ada dua landasan paradigma yang terkandung dalam ajaran wakaf itu sendiri yaitu paradigma ideologis dan paradigma social ekonomi. Secara ideologis wakaf memiliki ajaran ideology yang sangat kental sebagai kelanjutan dari ajaran tauhid. Yaitu, segala sesuatu yang berpuncak kepada keyakinan terhadap keesaanTuhan harus dibarengi dengan kesadaran akan perwujudan keadilan sosial. Islam mengajarkan kepada ummatnya agar meletakkan persoalan harta (kekayaan dunia) yang dimiliki oleh seseorang atau sebuah lembaga harus mempunyai kandungan nilai-nilai sosial (humanistic). Prinsip kepemilikan harta dalam Islam menyatakan bahwa harta tidak dibenarkan hanya dikuasai oleh sekelompok orang.

Sedangkan paradigma sosial-ekonomi, wakaf memiliki kontribusi solutif terhadap persoalanpersoalan ekonomi kemasyarakatan. Dalam tataran ini wakaf menjadi jawaban yang konkrit dalam realitas problematika kehidupan (sosial-ekonomi) masyarakat.

Sejak agama Islam masuk kewilayah nusantara, wakaf telah menjadi bagian dari praktek keberagamaan ummat Islam. Institusi perwakafan di Indonesia berasal dari hukum Islam itu sendiri yang telah dikenal bersamaan dengan kehadiran agama Islam di Indonesia. ${ }^{4}$

Terdapat beberapa pokok persoalan yang menjadi tantangan didalam mengembangkan serta mengoptimakan manfaat dari harta benda wakaf yaitu: harta benda wakaf masih dikelola secara tradisional, tanah wakaf tidak produktif, pola piker nazhir masih tradisional, wakaf uang belum tersebar luas, dan lain-lain. ${ }^{5}$

\footnotetext{
${ }^{1}$ Departemen Agama RI, “Wakaf Tunai dalam Perspektif Hukum Islam” Direktorat Jenderal Bimbingan Masyarakat Islam dan Penyelenggaraan Haji DirektoratPengembangan Zakat danWakaf, ( Jakarta : 2005 ), hal.13-14

${ }^{2}$ Kementerian Agama RI “ Undang-UndangNomor 41 Tahun 2004 Tentang Wakaf", Direktorat JenderalBimbingan Masyarakat Islam Direktorat Pemberdayaan Wakaf, (Jakarta:2013), Hal.2-3

${ }^{3}$ Kementerian Agama RI,"Pedoman Pengelolaan \& Pengembangan Wakaf", Direktorat Jenderal Bimbingan Masyarakat Islam dan Penyelenggaraan Haji, ( Jakarta:2003), Hal. 7-8

${ }^{4}$ Ibid
}

5 Ade Fajar,"Lembaga Wakaf dalam mengelola Potensi Wakaf di Indonesia" ,https/indonesiana. tempo.co/read/111714/2017 
Meski wakaf merupakan salah satu sumber kemajuan ekonomi ummat Islam, bukan berarti didalam mengembangkanpotensi wakaf serta didalam mengelola harta benda wakaf tersebut tidak mengalami kendala dan kesulitan. Menurut Direktur Eksekutif Badan wakaf Indonesia (BWI) Achmad Djunaedi, beberapa persoalan yang menjadi kendala tersebut antara lain: Pertama, banyaknya masjid tua diperkotaan yang dimasukkan dalam cagar budaya, hal ini mengakibatkan masjid tersebut tidak dapat dikembangkan. Di Jakarta misalnya ada SK Gubernur DKI Nomor 475 Tahun 1993 ( Tentang Penetapan Bangunan-Bangunan Bersejarah di DKI Jakarta sebagai Benda Cagar Budaya ). Aturan ini masih berlaku sampai saat ini, sehingga termasuk bangunan masjid yang masuk ke dalam kategori benda cagar budaya secara otomatis tidak dapat dipugar untuk dikembangkan dengan pengelolaan yang lebih profesional; Kedua, Badan Wakaf Indonesia ( BWI ) tidak mendapatkan sokongan dana dari Kementerian Agama. Hal ini disebabkan karena mata anggarannya masih ditautkan ke dalam bantuan sosial ( bansos ) yang peruntukannya hanya pada situasi kerentanan sosial, bukan pada kebutuhan operasional sebuah lembaga; Ketiga, pengelolaan tanah wakaf di Indonesia masih berkarakter tradisional dan tidak profesional. Sehingga mereka kurang paham mengenai aspek legalitas tanah wakaf saat ini masih banyak tanah wakaf yang belum bersertifikat wakaf. ${ }^{6}$

Menteri Agraria dan Tata Ruang / Kepala Badan Pertanahan Nasional ( ATR/BPN ) Sofyan Djalil mengatakan, program Sertifikasi tanah wakaf terus berjalan karena merupakan bagian dari program Sertifikasi tanah di Indonesia. Tanah wakaf jumlahnya sangat banyak, sehingga BPN tidak bisa melakukan sendiri program Sertifikasi tanah wakaf, sehingga masyarakat harus pro aktif. la menjelaskan dengan memiliki Sertifikat maka harta benda wakaf akan terjamin sehingga harta benda wakaf tersebut tidak sampai hilang, dijual dan rusak. Menurutnya, biasanya ketika harta tanah sudah mahal, keluatga yang mewakafkan dikhawatirkan mempersoalkan kembali tanah yang sudah diwakafkan, biasanya ada yang menarik kembali tanah wakaf. Berdasarkan data dari Dewan Masjid Indonesia ( DMI ), sekitar 40 \% tanah wakaf sudah disertifikasi, namun pada kenyataannya jumlah tanah wakaf terus bertambah. Maka dari itu diperlukan kerja sama dengan lembaga-lembaga keagamaan untuk menjalankan program Sertifikasi tanah wakaf. ${ }^{7}$

Kendati proses wakaf sudah terjadi dan dikenal sejak dahulu kala, bahkan sejak jaman sebelum lahirnya agam Islam, namun wakaf tidak akan pernah lepas dari persoalan. Seiring dengan perkembangan jaman berkembang pula segala persoalan yang mengikuti serta timbul terhadap harta benda wakaf. Seperti legalitas harta benda wakaf, biaya sertifikasi harta benda wakaf, sumber daya manusis ( nazhir ) dalam mengelola harta benda wakaf, dimasukkannnya bangunan - bangunan masjid tua ke dalam bangunan cagar budaya, pengelolaan harta benda wakaf secara tradisional, tidak adanya anggaran untuk Badan Wakaf Indonesia ( BWI ) dari Kementerian Agama, kurangnya kerja sama antar Lembaga Negara secara maksimal.

Dari sekian banyak problematika yang terjadi di dalam pelaksanaan wakaf, ada yang menarik terhadap perhatian penulis, yaitu semakin meningkatnya animo masyarakat untuk mewakafkan hartanya sehingga dapat dipergunakan untuk kepentingan umum terutama untuk kepentingan ummat Islam. Namun demikian tidak semua orang yang mewakafkan hartanya ( wakif ) menyadari betul mengenai legalitas dari harta benda wakaf tersebut, sehingga dikemudian hari tidak menutup kemungkinan apabila harta benda wakaf tersebut malah justru akan menimbulkan persoalan. Sehingga kemudian munculah Undang-Undang Nomor 41 Tahun 2004 Tentang Wakaf dan Peraturan Pemerintah Nomor 42 tahun 2006 Tentang Pelaksanaan Undang-Undang Nomor 41 Tahun 2004 Tentang Wakaf, Serta Peraturan Menteri Agama Nomor 4 tahun 2009 Tentang Administrasi

\footnotetext{
${ }^{6}$ Achmad Djunaedi,"Pengelolaan wakaf masih hadapi kendala", Sm.republika.co.id

${ }^{7}$ Sofyan Djalil,"Pentingnya sertifikasi tanah wakaf",
} 
Pendaftaran Wakaf Uang.

Jika legalitas harta benda wakaf tidak cukup melalui Akta Ikrar Wakaf ( AIW ) yang diterbitkan oleh Pejabat Pembuat Akta Ikrar Wakaf ( PPAIW ), maka tentu dikemudian hari akan menimbulkan persoalan baru dimasyarakat. Sebab Hukum Syari tidak mewajibkan adanya sertifkasi tanah wakaf sebagai syarat sah wakif dalam mewakafkan hartanya, namun harus diakui bahwa sertifikat merupakan dokumen berkekuatan hukum untuk melindungi harta benda wakaf tersebut.

Sementara disisi lain Kementerian Agama Republik Indonesia melalui Direktur Pemberdayaan Wakaf Republik Indonesia Dr. H. Suardi Abbas, SH. MH mengakui bahwa Kementerian Agama Republik Indonesia Sudah memprogramkan kewajiban terhadap lahan yang sudah diwakafkan atau dihibahkan untuk disertifikasi. Sebab selama ini banyak lahan yang sudah diwakafkan akhirnya digugat oleh ahli warisnya, terutama untuk tempat ibadah dan fasilitas umum lainnya. ${ }^{8}$

Kantor Kementerian Agama Kota Salatiga menjadi fokus bagi penulis untuk meneliti dan mengupas implementasi Undang-Undang Nomor 41 Tahun 2004 Tentang Wakaf terhadap legalitas tanah wakaf di Kantor Kementerian Agama Kota Salatiga.Dan memberikan gambaran betapa pentingnya Legalitas untuk kemaslahatan bersama yaitu untuk menghindari konflik antara ahli waris dari wakaf tersebut jika wakaf sudah di legalkan. Ahli waris tidak bisa menggugat harta yang di wakafkan tersebut karena sudah ada bukti secara otentik dimana keabsahan dari legalitas harta benda wakaf tersebut dapat dipertanggungjawabkan.

\section{PEMBAHASAN}

\section{Makna Wakaf}

Wakaf, berasal dari bahasa Arab al-waqf bentuk masdar dari kata"waqafa-yaqifu-waqfan Kata al-waqf semakna dengan al-habs bentuk masdar dari "habasa-yahbisu-habsan"artinya menahan. ${ }^{2}$ Dalam bahasa Arab, istilah wakaf kadang-kadang bermakna objek atau benda yang diwakafkan (al-mauquf bih) atau dipakai dalam pengertian wakaf sebagai institusi seperti yang dipakai dalam perundang-undangan Mesir. Di Indonesia, term wakaf dapat bermakna objek yang di-wakafkan atau institusi.

Menurut istilah meskipun terdapat perbedaanpenafsiran, disepakati bahwa makna wakaf adalah menahan dzatnya benda dan memanfaatkan hasilnya atau menahan dzatnya dan menyedekahkan manfaatnya. ${ }^{4}$ Adapun perbedaan pen-dapat para ulama fiqh dalam men-definisikan wakaf diakibatkan cara penafsiran dalam memandang hakikat wakaf. Perbedaan pendangan tersebut dapat diuraikan sebagai berikut; berikut :

Secara epistemologis, yang dimaksud dengan wakaf menurut ulama fikih adalah sebagai

Pertama, menurut Mazhab Hanafi Wakaf adalah menahan benda orang yang berwakaf ( wakif ) dan mensedekahkan manfaatnya untuk kebaikan. Lebih lanjut menurut Mazhab Hanafi mewakafkan harta bukan berarti meninggalkan hak milik secara mutlak, dan orang yang mewakafkan boleh saja menarik wakafnya kembali kapan saja ia kehendaki dan boleh diperjual belikan oleh pemilik semula. Namun pada kesempatan lain, Mazhab Hanafi mengakui keberadaan harta wakaf yang tidak dapat ditarik kembali, yaitu :

a. Berdasarkan keputusan hakim bahwa harta wakaf itu tidak boleh dan tidak dapat ditarik kembali;

b. Wakaf itu dilakukan dengan jalan wasiat;

c. Harta wakaf yang dipergunakan untuk pembangunan masjid.

Kedua, menurut Mazhab Maliki wakaf adalah menjadikan manfaat harta benda sang wakif baik

\footnotetext{
${ }^{8}$ Dr.H.Suardi Abbas,SH, MH,"Tanah wakaf wajib bersertifikat", diakses tanggal , harian rakyat bengkulu.com
} 
berupa sewa atau hasilnya untuk diserahkan kepada orang yang berhak, dengan bentuk penyerahan berjangka waktu sesuai dengan apa yang dikehendaki oleh orang yang mewakafkan(wakif).Berdasarkan divinisi tersebut seseorang yang mewakafkan hartanya dapat menahan penggunaan harta benda tersebut secara penuh dan membolehkan pemanfaatan hasilnya untuk tujuan kebajikan, dengan tetap kepemilikan harta pada diri sang wakif. Adapun masa berlakunya harta yang diwakafkan tidak untuk selama-lamanya, melainkan hanya untuk jangka waktu tertentu sesuai kehendak orang yang mewakafkan pada saat mengucapkan shighat ( akad ) wakaf. Oleh karenanya bagi Mazhab Maliki, tidak disyaratkan wakaf untuk selama-lamanya.

Ketiga, Menurut Mazhab Syafi'i wakaf adalah menahan harta yang dapat diambil manfaatnya, dengan tetap utuhnya barang, dan barang tersebut lepas dari milik orang yang mewakafkan ( wakif ), serta dimanfaatkan untuk sesuatu yang diperbolehkan oleh agama.Berdasarkan pengertian tersebut, Mazhab Syafi'i memiliki sikap yang sangat tegas terhadap status kepemilikan harta wakaf, yaitu dengan sahnya wakaf maka kepemilikan harta wakaf telah berpindah kepada Allah, dalam arti milik ummat, dan bukan lagi milik orang yang mewakafkan dan juga milik nazhir pekerja pengelola wakaf.

Kempat, menurut Mazhab Hambali wakaf adalah menahan secara mutlak kebebasan pemilik harta dalam membelanjakan hartanya yang bermanfaat dengan tetap utuhnya harta, dan memutusan semua hak penguasaan terhadap harta tersebut, sedangkan manfaatnya diperuntukkan bagi kebaikan dalam rangka mendekatkan diri pada Allah.Berdasarkan pada pengertian ini, Mazhab Hambali berpendirian bahwa apabila suatu wakaf sudah sah, maka hilanglah kepemilikan orang yang mewakafkan tersebut atas harta yang diwakafkannya. ${ }^{9}$

\section{Dasar Hukum Wakaf}

1) Wakaf dalam Al-Qur'an

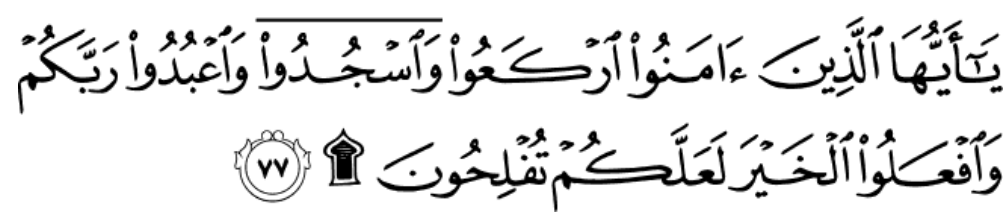

Terjemahnya: "Hai orang-orang yang beriman, ruku'lah kamu, sujudlah kamu, sembahlah Tuhanmu dan perbuatlah kebajikan, supaya kamu mendapat kemenangan". (QS. Al-Hajj (22): 77)

Kata khair (kebaikan) yang secara umum dimaknai salah satunya dalam bentuk memberi seperti wakaf, dan berlaku untuk bentuk-bentuk charity atau endowment yang lain yang bersifat filantropi, tentunya dalam ajaran Islam

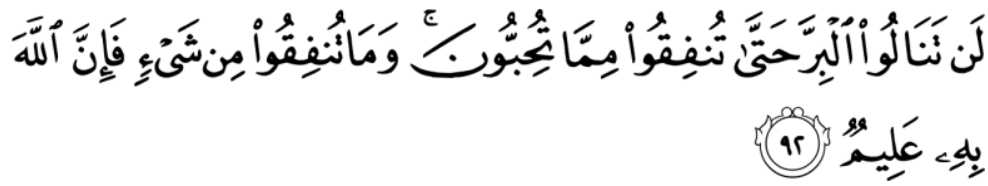

Terjemahnya:"Kamu sekali-kali tidak sampai kepada kebajikan (yang sempurna), sebelum kamu menafkahkan sebahagian harta yang kamu cintai. dan apa saja yang kamu nafkahkan Maka Sesungguhnya Allah menge-tahuinya". (QS. Ali Imran (3): 92)

2) Wakaf dalam hadist

Ada beberapa hadis yang dianalisis menjelaskan tentang wakaf. Hadis-hadis tersebut antara lain:

"Dari Abi Hurairah r.a. sesunggunya Rasulullah Saw berkata: jika seseorang telah meninggal dunia, maka terputuslah semua amal dari dirinya kecuali tiga, yaitu sadakah jariyah, ilmu yang

\footnotetext{
${ }^{9}$ Departemen Agam RI, “Wakaf Tunai dalam Perspektif Hukum Islam”, Direktorat Jenderal Bimbingan Masyarakat Islam dan Penyelenggaraan Haji Direktorat Pengembangan Zakat dan Wakaf, ( Jakarta : 2005 ), hal. 13-14
} 
bermanfaat dan anak saleh yang mendoakan kepadanya (kepada orang tuanya)".

\section{Unsur (rukun) Wakaf}

Wakaf dinyatakan sah apabila telah terpenuhi rukun dan syaratnya. Rukun wakaf menurut fiqh ada 4 (empat) macam, yaitu; ${ }^{10}$

1) Waqif (orang yang mewakafkan)

Waqif adalah pihak yang mewakaf-kan. Wakif harus mempunyai keca-kapan hukum atau kamalul ahliyah (legal competent) dalam membelan-jakan hartanya (tasharruf al-mal). Kecakapantersebut meliputi 4 kriteria,yaitu: Merdeka, Berakal sehat, Dewasa (baligh), tidak dibawah pengampuan

2) Mauquf'alaih (pihakyangdiserahi wakaf)

Mauquf 'alaih dalam literatur fiqh kadang diartikan orang yang diserahi mengelola harta wakaf, yang sering disebut nadzir, kadang juga diartikan peruntukan harta wakaf. Bila diartikan mauquf 'alaih sebagai nadzir, dalam literatur fiqh kurang mendapat porsi pembahasan yang detail oleh para ahli fiqh yang terpenting adalah keberadaan mauquf 'alaih mampu mewujudkan peruntukan benda wakaf (makna lain dari mauquf 'alaih). Hal ini ter-pengaruh oleh unsur tabarru' (kebaikan) yang meliputi peruntukan ibadah dan sosial (umum) kecuali yang bertentangan dengan Islam (ideologi) dan maksiat. Pengaruh lain adalah karena pemahaman bahwa wakaf termasuk akad sepihak yang tidak membutuhkan adanya qabul dan salah satu pendapat boleh hukumnya wakaf kepada diri sendiri.

3) Mauquf (harta yang diwakafkan)

Berbicara tentang mauquf atau harta yang diwakafkan dalam fiqih tentu tak terlepas dari dua hal yaitu,pertama, jenis harta, apakah benda bergerak atau tidak bergerak, atau bisa keduanya. Madzhab Syafi'iyah dan Hanbaliyah tergolong konservatif dengan hanya membolehkan harta tak bergerak sebagai objek wakaf. Sementara Hanafiyah dan Malikiyah cenderung membolehkan wakaf harta bergerak. Perbedaan ini muncul dari perbedaan menafsirkan apakah yang diwakafkan adalah dzat benda atau manfaat benda. Bila dzat benda maka cenderung benda tidak bergerak yang ternyata jumlah jenisnya sedikit, sedangkan bila man-faat benda cenderung benda bergerak yang jumlah jenisnya sangat banyak.

Keterkaitan antara status kepemili-kan wakif terhadap benda wakaf setelah diwakafkan berimplikasi pada kewenangan atas perlakuan wakif ter-hadap benda wakaf tersebut yang oleh hadis riwayat umar memuat tiga tin-dakan yaitu dijual, dihibahkan dan diwariskan. Terhadap hal tersebut Abu Hanifah menyatakan bahwa harta wakaf masih milik wakif, maka wakif boleh memperlakukan apa saja ter-hadap harta wakaf seperti menjual, menghibakan, dan mewariskan termasukmengagunkanharta benda wakaf. berbedadenganHanafi,Maliki sekalipun menyatakan bahwa harta wakaf milik wakif, tetapi wakif tidak punya hak untuk mendayagunakan harta wakaf secara pribadi dalam bentuk apapun. SedangkanSyafi'idanHanbali menyata-kan putusnya kepemilikan harta wakaf dengan wakif sehingga wakif terputus haknya terhadap harta wakaf. Kedua, kelanggengan atau keabadian objek wakaf yang terkait erat dengan objek wakaf yang bergerak. Oleh karena itu mewakafkan harta bergerak harus melekat dengan harta tak bergerak seperti wakaf alat pertanian terkait dengan sawah, dan sebagainya. ${ }^{11}$

Hal yang menarik lagi adalah perubahan peruntukan. Jika suatu ketika benda wakaf itu sudah tidak ada manfaatnya atau sudah berkurang manfaatnya, kecuali ada perubahan pada benda wakaf tersebut, seperti menjual, merubah bentuk asal, memin-dahkan ke tempat lain, atau menukar dengan benda lain, bolehkan per-ubahan itu dilakukan terhadap benda wakaf tersebut? Ternyata dalam hal

\footnotetext{
${ }^{10}$ http://jurnaldiktum.blogspot.co.id/2015/01/wakaf-dalam-perspektif-fikhi-dan-hukum.html., 13.41.

${ }^{11}$ Mohammad Daud Ali (1988). Sistem Ekonomi Islam, Zakat dan Wakaf. (Jakarta: UI Press), hlm. 93
} 
tersebut para ulama fiqh berbeda pendapat.

Perubahanstatus, penggantian benda dan tujuan wakaf, sangat ketat peng-aturannya dalam madzhab Syafi'i. namun demikian, berdasarkan keadan darurat dan prinsip mashlahah, dikalangan para ulama figh perubahan itu dalam dilakukan. Ini disandarkan pada pandangan agar manfaat wakaf itu tetap terus berlangsung sebagai sadaqah jariyah, tidak mubadzir karena rusak, tidak berfungsi lagi dan sebagainya. ${ }^{12}$

4) Shighat atau iqrar (pernyataan atau ikrar wakif sebagaisuatukehendakuntuk mewakaf-kan)

Shighat atau ikrar adalah pernyataan penyerahan harta benda wakaf oleh wakif. Dalam hal ini perbedaan yang muncul adalah bentuk pernyataan apakah lisan, kinayah atau tindakan. Sementara dalam hal akad wakaf, semua madzhab menyatakan bahwa wakaf adalah akad tabarru' yaitu transaksi sepihak yang sah sebagai suatu akad yang tidak memerlukan kabul dari pihak penerima dan dicukupkan dengan ijab si wakif. Akad tidaklah menjadi syarat dalam akad wakaf. Definisi akad disini adalah suatu bentuk perbuatan hukum (tasharruf) yang mengakibatkan adanya kemestian penataan kepada apa yang dinyatakan dari kehendak per-buatan hukum itu oleh pihak yang berkepentingan, kendatipun pernyataan itu dari sepihak saja. Akad dalam pengertian kesepakatan dari dua belah pihak yang berkehendak melakukan suatu perikatan digambarkan dengan ijab dan qabul seperti yang terjadi dalam jual beli, sewa menyewa, dan sebagainya, sehingga tidaklah berlaku dalam pengertian akad wakaf. $^{13}$

\section{Bentuk-bentuk Wakaf}

Adapun bentuk-bentuk wakaf tersendiri dalam hukum Islam dibagi menjadi dua sesuai dengan tujuan pemberian wakaf tersebut, dalam arti lain disesuaikan peruntukannya yaitu;

1) Wakaf ahli

Wakaf ahli yaitu wakaf yang ditujukan kepada orang-orang tertentu, seorang atau lebih, baik keluarga si wakif atau bukan. Wakaf ahli juga sering disebut wakaf dzurri atau wakaf 'alal aulad yakni wakaf yang diper-untukan bagi kepentingan dan jaminan sosial dalam lingkungan keluargaataulingkungankerabat sendiri ${ }^{14}$

2) Wakaf Khoiri

Wakaf khoiri yaitu wakaf yang secara tegas untuk kepentingan ke-agamaan atau kemasyarakatan (kepen-tingan umum). Wakaf ini ditujukan untuk kepentingan umum dengan tidak terbatas pada aspek penggunannya yang mencakup semua aspek untuk kepentingan dan kesejahteraan umat manusia pada umumnya. Kepentingan umum tersebut bisa untuk keagamaan, jaminan sosial, pendidikan, kesehatan, keamanan dan lain-lain, yang dapat berwujud seperti pembangunan masjid, sekolah, jembatan, rumah sakit, panti asuhan anak yatim dan sarana sosial lainnya.

\section{Implementasi Undang-Undang Nomor 41 Tahun 2004}

Meningkatnya kesadaran dan kemauan masyarakat muslim Indonesia untuk melaksanakan ibadah wakaf serta semakin berkembangnya model pengelolaan harta benda wakaf, menjadi faktor utama bertambah banyaknya harta benda wakaf yang dimiliki oleh Kementerian Agama Republik Indonesia. Dengan bertambahnya jumlah serta model pengelolaan harta wakaf tersebut tentu membawa dampak yang luar biasa bagi umat Islam. Baik dampak secara ekonomi maupun dampak

\footnotetext{
${ }^{12}$ Sayyid Sabiq (1977). Fiqhu as-Sunnah. (Lebanon: Dar al-'Arabi), hlm. 387; Abil Mawahib bin Ahmad Abdul Wahab (t.t.). Mizan al-Kubro. (Mesir: Dar Ahya al-Kutub al-'Arabiyyah), hlm. 228.

${ }^{13}$ Al-Kabisi. Hukum Wakaf, hlm. 95

${ }^{14}$ UU No. 41 Tahun 2004 tentang Wakaf pasal 1 ayat (1).
} 
secara hukum terkait dengan legalitas dari tanah wakaf tersebut.

Sebagai wujud respon atas fakta di atas Pemerintah mengeluarkan Undang-Undang Nomor 41 Tahun 2004 Tentang Wakaf serta Peraturan Pemerintah Nomor 42 Tahun 2006 Tentang Pelaksanaanya dan Peraturan Menteri Agama Nomor 4 tahun 2009 Tentang Administrasi Pendaftaran Wakaf Uang.

Ada poin penting dalam Undang-Undang Nomor 41 Tahun 2004, tentang pendaftaran dan pengumuman harta benda wakaf, dimana poin tersebut berkaitan erat degan status legalias tanah wakaf. Kebijakan Pemerintah didalam mengatur serta mengeluarkan Undang-Undang Nomor 41 Tahun 2004 Tentang Wakaf ini menarik untuk dilihat dari sudut pandang implementasinya terhadap masyarakat atas regulasi dari Undang-Undang Nomor 41 Tahun 2004 Tentang Wakaf yang berlaku sebagai dasar serta acuan di dalam mengelola dan mendafarkan harta benda wakaf tang menjadi pedoman bagi masyarakat muslim khususnya di lingkungan Kantor Kementerian Agama Kota Salatiga.

Perkembangan wakaf di Indonesia dapat dikatakan sejalan dengan perkembangan penyebaran Islam. Pada masa-masa awal penyiaran Islam, kebutuhan terhadap masjid untuk menjalankan aktifitas ritual dan dakwah berdampak sangat positif, yakni pemberian tanah wakaf untuk mendirikan masjid menjadi tradisi yang lazim dan meluas di komunitas Islam di Nusantara. Seiring dengan perkembangan sosial masyarakat Islam dari waktu ke waktu praktik perwakafan mengalami kemajuan setahap demi setahap. Tradisi wakaf untuk tempat ibadah tetap bertahan dan mulai muncul wakaf lain untuk kegiatan sosial dan kesehatan, seperti wakaf untuk pendirian klinik dan kesehatan.

Dalam perjalanannya, sejarah wakaf terus berkembang dan akan selalu berkembang bersamaan dengan laju perubahan zaman dengan berbagai bentuk inovasi yang relevan, seperti bentuk wakaf uang, wakaf atas hak kekayaan intelektual (HAKI), dan lain-lain. Di Indonesia pada saat ini wakaf semakin mendapatkan perhatian yang cukup serius dengan diterbitkannya Undang-Undang Nomor 41 Tahun 2004 Tentang Wakaf dan Peraturan Pemerintah Nomor 42 Tahun 2006 Tentang Pelaksanaannya serta Peraturan Menteri Agama Nomor 4 Tahun 2009 Tentang Administrasi Pendaftaran Wakaf Uang.

Keadaan tanah wakaf pada Kantor Kementerian Agama Kota Salatiga jumlah tanah wakaf tersebar dan terbagi dalam empat wilayah kecamatan atau Kantor Urusan Agama (KUA). Adapun jumlah dari tahun ke tahun mengalami perubahan serta penambahan lokasi bidang tanah wakaf. Hal tersebut dapat dilihat dari tabel dibawah ini sebagai gambaran dari keadaan bidang tanah wakaf di Kantor Kementerian Agama Kota Salatiga. Tahun ke tahun mengalami penambahan jumlah tanah wakaf serta mengalami perubahan kondisi administrasi baik yang berkaitan dengan Akta Ikrar Wakaf (AIW), sertifikasi tanah wakaf, maupun hal lain yang berkaitan dengan persoalan wakaf.

\section{Hambatan Implementasi Kebijakan Undang-Undang Nomor 41 Tahun 2004}

Kebijakan legalitas tanah wakaf sesuai dengan Undang-undang nomor 41 tahun 2004 Tentang Wakaf, Peraturan Pemerintah Nomor 42 tahun 2006 Tentang Pelaksanaannya, mempunyai implikasi luar biasa bagi masyarakat sesuai dengan segala kewenangannya Kantor Kementerian Agama Kota Salatiga berkewajiban mengawal regulasi undang-undang tersebut. Didalam melaksanakan kewajibannya itu ditemukan beberapa persoalan dan hambatan, namun demikian Kantor kementerian Agama Kota Salataiga memiliki tanggungjawab moril untuk menemukan solusi atas persoalan dan hambatan tersebut. Adapun Hambatan yang dihadapi serta solusi yang diberikan adalah sebagai berikut;

1) Kurangnya sosiaisasi pada seluruh lapisan masyarakat mengenai kebijakan pemerintah tentang undang-undang no. 41 tahun 2004 tentang wakaf serta peraturan pemerintah nomor 42 tahun 


\section{6 tentang pelaksanaanya.}

2) Kurangnya kerjasama dengan organisasi keagamaan, tokoh agama, tokoh masyarakat, media cetak dan elektronik untuk melakukan sosialisasi undang-undang no.41 tentang wakaf dan peraturan pemerintah nomor 42 tahun 2006

3) Belum adanya sanksi yang tegas terhadap seluruh unsure yang berkaitan dengan pengelolaan benda wakaf dengan secara sengaja melakukan pelanggaran terhadap undang-undang tersebut

4) MUI belum mengeluarkan fatwa mengenai pentingnya legalitas tanah tersebut di lihat dari pespektif undang-undang nomor 41 tahun 2004 tentang wakaf

\section{Solusi Implementasi Undang-Undang Nomor 41 Tahun 2004}

1. Melakukan sosialisasi kepada seluruh lapisan masyarakat mengenai kebijakan pemerintah tentang Undang-undang nomor 41 tahun 2004 Tentang Wakaf serta Peraturan Pemerintah Nomor 42 tahun 2006 Tentang Pelaksanaannya.

2. Melakukan kerjasama dengan organisasi keagamaan, tokoh agama, tokoh masayarakat, media cetak dan elektronik, untuk melakukan sosialisasi Undang-undang nomor 41 tahun 2004 Tentang Wakaf, Peraturan Pemerintah nomor 42 tahun 2006 Tentang Pelaksanaannya.

3. Menerapkan sanksi terhadap seluruh unsur yang berkaitan dengan pengelolaan harta benda wakaf yang secara sengaja melakukan pelanggaran terhadap Undang-undang tersebut.

4. Mendorong MUI untuk memperkuat fatwa tentang pentingnya legalitas tanah wakaf dilihat dari persepektif Undang-undang nomor 41 tahun 2004 Tentang Wakaf.

\section{KESIMPULAN}

Pelaksanaan Undang-undang No.41 Tahun 2004 tentang Wakafkeberadaannya memilikiposisi yang sangat penting bagi perkembangan pengelolaan harta benda wakaf, terutama terkait terhadap keabsahan legaitas dari harta benda wakaf. potensi nilai dari pengelolaan harta benda wakaf yang besar dan perannya sangat strategis dalam penanggulangan kemiskinan dan peningkatan kesejahteraan masyarakat. Kemudian beberapa kelemahan-kelemahan yang ada didalam mengimplementasikan Undang-Undang tersebut adalah sebagai berikut :

1) Melakukan sosialisasi kepada seluruh lapisan masyarakat mengenai kebijakan pemerintah tentang Undang-undang nomor 41 tahun 2004 Tentang Wakaf serta Peraturan Pemerintah Nomor 42 tahun 2006 Tentang Pelaksanaannya.

2) Melakukan kerjasama dengan organisasi keagamaan, tokoh agama, tokoh masayarakat, media cetak dan elektronik, untuk melakukan sosialisasi Undang-undang nomor 41 tahun 2004 Tentang Wakaf, Peraturan Pemerintah nomor 42 tahun 2006 Tentang Pelaksanaannya.

3) Menerapkan sanksi terhadap seluruh unsur yang berkaitan dengan pengelolaan harta benda wakaf yang secara sengaja melakukan pelanggaran terhadap Undang-undang tersebut.

4) Mendorong MUI untuk memperkuat fatwa tentang pentingnya legalitas tanah wakaf dilihat dari persepektif Undang-undang nomor 41 tahun 2004 Tentang Wakaf.

\section{DAFTAR PUSTAKA}

\section{Undang-Undang Nomor 41 Tahun 2004 Tentang Wakaf}

DepartemenAgama RI, "Wakaf Tunai dalamPerspektif Hukum Islam" Direktorad Jenderal Bimbingan Masyarakat Islam danPenyelenggaraan Haji Direktorat Pengembangan Zakat dan Wakaf, (Jakarta:2005) 
Kementerian Agama RI" Undang-Undang Nomor 41 Tahun 2004 Tentang Wakaf", DirektoratJenderal Bimbingan Masyarakat Islam Direktorat Pemberdayaan Wakaf, (Jakarta:2013)

Kementerian Agama RI,"Pedoman Pengelolaan\&Pengembangan Wakaf", Direktorat Jenderal Bimbingan Masyarakat Islam dan Penyelenggaraan Haji,(Jakarta:2003)

Mohammad Daud Ali,"Sistem Ekonomi Islam,Zakatdan Wakaf",(Jakarta.UI Press:1998)

Sayyid Sabiq ,"Fiquha Assunnah ,Abil Mawahib bin Ahmad Abdul Wahab Mizal Al Kubro (Mesir 1977)

Abd al Wahab al Khallaf,Ilm Ushul al Fiqh, Jakarta:Maktabah al Da'wah al Islamiyah Syabab al Azhar,1410/1990

Abd al-Rahman al-Jaziri, Kitab al-Fiqh 'ala al-Madhahib al-Arba'ah (t.tp.: Dar al- Irshad, t.t.), jilid 1

Abd al-Rahman al-Jaziri, Kitab al-Figh 'ala al-Madhahib al-Arba'ah (t.tp.: Dar al- Irshad, t.t.), jilid 1

Abd. Muin Salim, Konsepsi Kekuasaan Politik Dalam Al-Qur'an (Cet. II; Jakarta: RajaGrafindo Persada, 1995),

Abil Mawahib bin Ahmad Abdul Wahab (t.t.). Mizan al-Kubro. Mesir: Dar Ahya al-Kutub al-'Arabiyyah.

Abu Zahrah (1971). Mhadharat fi al-Waqo. Beirut: Dar al-Fikr al-'Arabi.

Akh. Minhaji (2005). "Nation State dan Implikasinya Terhadap Pemikiran dan Implementasi Hukum Wakaf", Kata Pengantar dalam Abdul Ghofur Anshori, Hukum dan Praktik Per-wakafan di Indonesia. Yogyakarta: Pilar Media.

Al-Baijuri (t.t.). Hasyiyah al-Baijuri. Beirut: Dar al-Fikr, II.

Adi Rianto, 2004, Metodologi Penelitian Sosial dan Hukum,Jakarta,Granit

Ali Fikri (1938). Al-Mu'amalat al-Maliyah wa al-Adabiyah. Mesir: Mushthafa al-Babi al-Halabi.

Asy-Syarbini (t.t.). Mugni al-Muhtaj. Kairo: Musthafa Halabi.

Bukhari (t.t.). Shahih Bukhari. Mesir: Dar al-Fikr al-Mu'ashir.

Chaidar S. Bamualim \& Irfan Abubakar (ed.) (2005). Revitalisasi Filantropi Islam: Studi Kasus Lembaga Zakat dan Wakaf di Indonesia. Jakarta: PBB UIN Syahid.

Departemen Agama RI, 2003, Pedoman Pengelolaan \& Pengembangan Wakaf, Jakarta, Direktorad Jenderal Bimbingan Masyarakat Islam dan Penyelenggaraan Haji

Departemen Agama RI, 2004, Strategi Pengembangan Wakaf Tunai di Indonesia, Jakarta, Direktorad Pengembangan Zakat dan Wakaf, Direktorad Jenderal Bimbingan Masyarakat Islam dan Penyelenggaraan haji

Ade Fajar,"Lembaga Wakaf dalam mengelola Potensi Wakaf di Indonesia", https/indonesiana.tempo.co/read/1117/14/2017

Achmad Djunaedi,"Pengelolaan wakaf masih hadapi kendala", Sm.republika.co.id

Dr.H.Suardi Abbas,SH,MH,"Tanah Wakaf Wajib Bersertifikat", harian rakyat bengkulu.com

http/jurnaldiktum.blogspot.co.id/2015/01/wakaf dalamperspektif fikih dan hukum 